\title{
LONG-TERM IMPACT OF CLOSING RURAL SCHOOLS ON LOCAL SOCIAL CAPITAL: A MULTIPLE-CASE STUDY FROM POLAND
}

\author{
Anna Kłoczko-Gajewska ${ }^{1}$
}

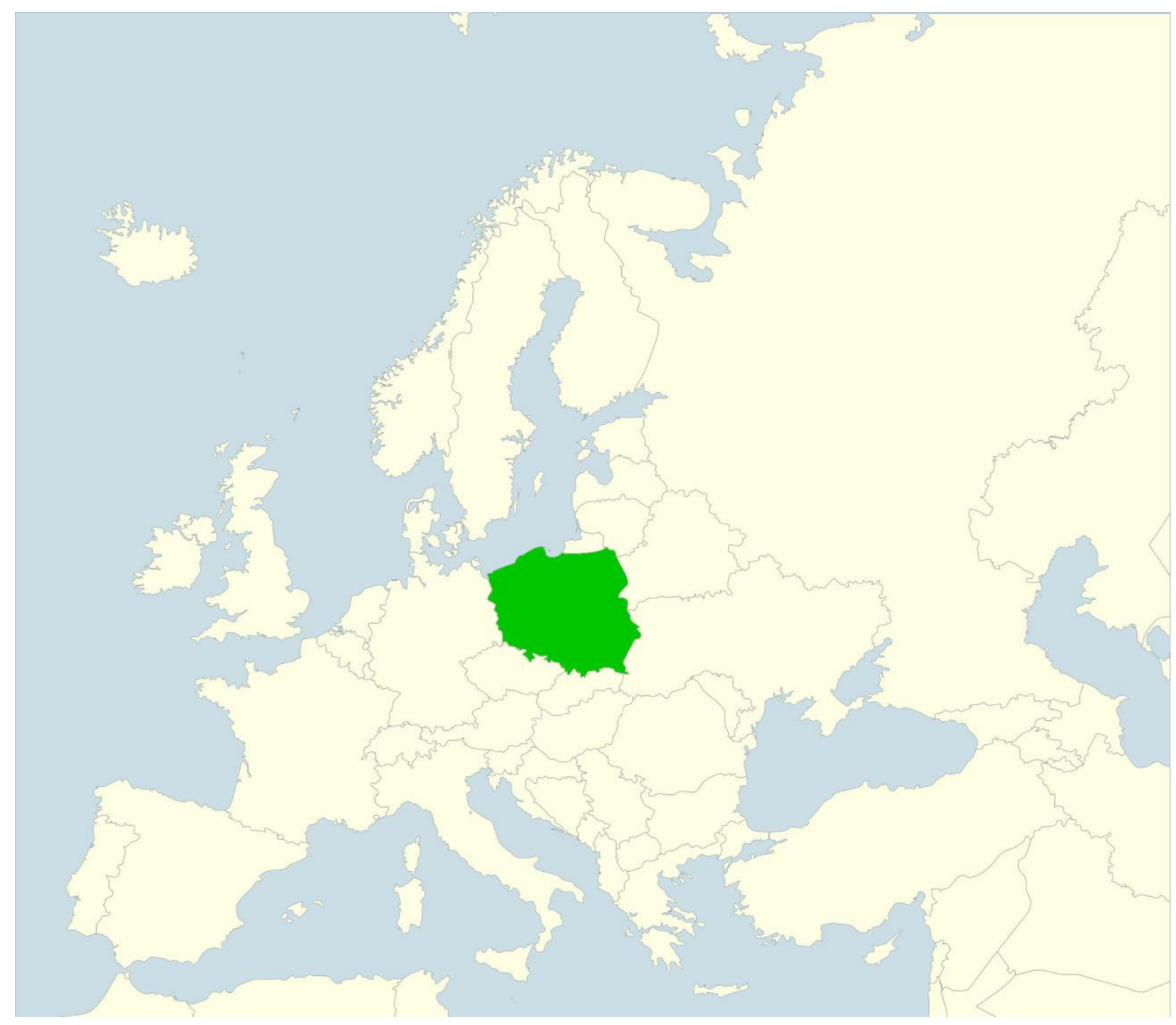

1 Anna Kłoczko-Gajewska, Warsaw University of Life Sciences - SGGW, Nowoursynowska 166, 02-787, Warsaw, Poland, ORCID: 0000-0002-6839-8831, anna_kloczko_gajewska@sggw.pl 
Abstract: In many European countries, for both demographic and financial reasons, small schools are being closed. A rural school is one of the few public places which enables formal and informal meetings of community residents. When it is closed, social activity changes. This paper presents a multiple-case study of four Polish villages which in the year 2000 organized protests against school closures; two schools were saved and two were closed. Semi-structured interviews with local leaders and office workers were conducted in 2004 and 2016. The study shows that the decline of structural social capital was significantly smaller in those villages where the school was saved. In the village in which the building of the school did not serve the local population due to the decision of the authorities, a significant and long-term decline in both structural and cognitive social capital was observed. That means that local authorities may contribute to the degradation of the local social capital.

Key words: rural schools, social capital, school closure, rural community, Poland

\section{Introduction}

Many European countries have for years attempted to create an effective rural education system. The reorganisations, putting aside effectiveness of teaching, affected not only the pupils and teachers, but the whole rural communities as well.

During the last century, similar trends in reforming educational systems were observable in Northern Europe, and I will describe them in short. Around the mid- $20^{\text {th }}$ century small schools were built in many villages to ensure easy access to them for pupils, then the schools were merged into larger, but more sparsely distributed educational centres (Aberg-Bengtsson, 2009), as the belief was that a school with only one teacher provides a lower level of education than a bigger unit (Hargreaves, 2009; Kalaoja, Pietarinen, 2009; Aberg-Bengtsson, 2009). With time the authorities returned to the idea of small schools close to the pupils, just to shut them down again, already in the $21^{\text {st }}$ century, as too costly, which was heavily influenced by both the decline in the number of school-aged children and the shift in the responsibility for schools to local governments without a significant increase in distributed resources (Kalaoja, Pietarinen, 2009; Aberg-Bengtsson, 2009; Kvalsund, 2019). In recent years, due to changes in financing, the number of rural schools declined also notably in Hungary (Kovács, 2012) and Poland (Domalewski, 2006). Of course, in each of those cases, the changes impacted both the direct stakeholders, i.e. the pupils, their parents and teachers, and indirectly, whole local communities. Unfortunately, the evidence of the impact of school opening or closure on the coherence of local communities is quite poor, as there is very little research on this topic. Thus, the aim of this paper is to describe and analyse changes in social capital in villages where the schools continue to operate in comparison to those where the schools were closed. More details on this issue will be given in the methods section.

\section{Rural schools and local communities}

In essence, there is a consensus among scholars as to the high importance of schools in rural communities (Hargreaves et. al., 2009). In many communities of New Zealand the school was the first public building to be erected, and the parents of pupils devoted their time and means for generations to equip the building or to organize a playground, treating the school's assets as a community goodwill (Witten et al., 2001). In Poland, fairly often the first rural schools were built by the community residents, or with materials donated by them. A village school is a place for meeting and sharing information, both formal and informal. Often, it is the last public institution in those villages where other organizations (health centres, post offices etc.) were moved away to larger settlements due to various reforms (Kalaoja, Pietarinen, 2009; Witten et al., 2001; Zhumashov, Tomanova, 2014; Jakubowski, Kozińska-Bałdyga, 2005; Domalewski, 2006) or to depopulation, observed in rural areas of many European countries (Viñas 2019). 
Informal meetings in neutral places are significant for the sense of belonging to a community, and in rural communities, various facilities, such as libraries, shops and, of course, schools, play a very important role, going beyond their formal tasks (Christiaanse, Haartsen, 2017; KarlbergGrandlund 2019; Young 2016). Schools organize cyclical events (Witten et al., 2001) and sporting events, which has a significant influence on the cohesion of the community. Such opportunities "to get involved and to belong" are crucial for creating resilient rural communities (Dwyer 2016, p. 178).

Teachers working in the school may constitute the intellectual elite of a given village, as they are at times the only people with higher education (Jakubowski, Kozińska-Bałdyga, 2005). They often engage in the local social life not only by organising school events, but also privately, as active and engaged citizens, although there are also cases when teachers try to separate their professional role from their private life and not play the role of community leaders (Raggl, 2015; Hargreaves et. al., 2009).

One should not forget that during a certain period of their lives, all children from the neighbourhood attend a local school, which strengthens social coherence (Witten et al., 2001). Moreover, the local school may be of emotional importance also for people who do not have school-age children, as it is treated as a symbol of vitality of the community (Christiaanse and Haartsen, 2017) - even though lately, this began to change (Kotarba 2017). Unfortunately, "[t]hese added meanings of facilities are rarely taken into account in empirical research on rural facility decline" (Christiaanse, Haartsen, 2017, p. 326).

It should not therefore be surprising that the threat of school closure evokes strong emotions and a feeling of loss (Christiaanse, Haartsen, 2017), and the role of small rural schools is especially stressed after their closure or when they are threatened with closure (Kalaoja, Pietarinen, 2009; Hargreaves, 2009; Aberg-Bengtsson, 2009; Hargreaves et. al., 2009). Parents' fears surrounding the closure of a school are not only related to the necessity of commuting to a new school, but also related to the feelings of children and the creation of a rift among the parents of other pupils (Witten et al., 2001). As the above review of literature clearly shows, "[t]he school is [...] perceived as having a pivotal role in the generation of social capital in the communities they serve." (Bagley, Hillyard, 2014, p. 69). Simultaneously, studies conducted in Great Britain (Bagley, Hillyard, 2014; Young 2016) show that local context should be perceived as very important.

There have been very few studies of rural schools conducted so far. For example, publications on schools in England can be divided into the following categories: "teaching and learning, parental choice, leadership and management, inter-school collaboration, and school and community relationships" (Hargreaves, 2009, p. 117-118). Hargreaves (2009, p. 124) makes the following remark about the study of school-community relations: "There is a case for systematic research and a need for peer-reviewed studies in this field. Many positive examples of school-community relationships are described, but analysis of their prevalence or prognosis is lacking". Similarly, in Finland, despite the ongoing process of centralization and the resulting closure of schools, the studies of impact of those events on local residents are lacking, especially those of longitudinal character (Kalaoja, Pietarinen, 2009). In Sweden, "there is [...] an urgent need of substantial research taking a broad perspective from the inside and below, [...] focusing on the importance of the school as a vital part of the rural community" (AbergBengtsson, 2009, p. 107), similarly as there is a need for research on the influence of rural school closure on the social life of the village, both in short and long term (Hargreaves et. al., 2009). Recent research concerning rural school embeddedness in Norway concentrates mostly on place-base and place-conscious education (Kvalsund, 2019). Also, Kramer (2019), while studying rural schools in Germany and Austria, uses an educational perspective, touching also on the problem of commuting. Raggl (2019) studies teaching conditions and learning context in small rural schools in Austria. There is some research concerning leadership in rural schools see for the literature review - Preston and Barnes (2017) - but it does not refer to the social capital in the surrounding community. Finally, Buzzard (2016) studied the changes of social activeness after the rural school closures in the USA, but without comparing it to the communities where the schools were still operating, thus missing possible changes influencing the whole society. 
Low interest among Polish researchers in the importance of schools for village communities may be proven by the fact that the "Village and Agriculture" monthly, a magazine published by the Institute of Rural and Agricultural Development of the Polish Academy of Sciences, has featured only one article on relationship between a rural school and village residents since 1999 (and it described the protest in defence of the school). Moreover, there were only several articles on other issues connected with rural schools (educational aspirations, the level of education of rural youth, and the educational system changes).

Existing literature on relations between social capital and education in Poland concentrates mostly on the influence of the community's social capital on pupils' school achievements, sometimes also on the influence of the level of education of individuals on their social capital (Mikiewicz, 2014; Guðmundsson, Mikiewicz 2012; Siellawa-Kolbowska, 2011) or the role of the educational system in rural development (Domalewski, 2010). Analyses of the influence of a local school on the level of social capital in the community are difficult to find, although there is a research on the short-term influence of creating a small kindergarten in a village community (Jaros et al., 2009). This paper will at least partly contribute to filling that gap.

\subsection{Conceptualization of social capital}

There are several approaches to the social capital concept. Bourdieu (1986) finds it a feature of an individual, while Putnam (2000) understands it as a feature of the community. Mikiewicz and Guðmundsson (2012) carried out an interesting overview of the concepts of social capital and concluded that two approaches of analysing school matters are possible: "education as a field of symbolic interplay and struggle for resources in the process of social allocation and reproduction" (Bourdieuian perspective) and "[s]chool as an element of local community affected both by social circumstances and affecting social realm within which it is settled Coleman's and Putnam's perspective" (Mikiewicz, Guðmundsson, 2012, p. 76). The latter approach seems more appropriate to the analysis of the community's reaction to the school closure (or threat of closure).

For instance, Autti and Hyry-Beihammer (2014) analysed social capital in the context of rural schools in Finland in two ways: "the role of the school as a producer and maintainer of local social capital and the role of local social capital in preventing school closure." (Autti and HyryBeihammer 2014, p. 2). In this research, the authors defined weak social capital as characterised by "a low level of social activity in the village and a reluctance to contribute to issues concerning the whole village", while villages with strong social capital were understood as places with vital social life and visible participation in volunteer work and associations (Autti, and Hyry-Beihammer, 2014, p. 8).

In this paper, social capital will be understood as "the norms and networks that enable people to act collectively" (Woolcock and Narayan, 2000, p. 226) - these norms may include trust and reciprocity, developed over time as a result of making various decisions. In this approach the society (and not the individual) is deemed a point of reference, but it accounts for the influence of individuals or government/self-government structures on the functioning of communities (Woolcock, Narayan, 2000).

According to the literature, social capital consists of structural social capital, i.e. roles, rules, precedents and networks that lead to mutually beneficial collective action, and cognitive social capital, which is less tangible, as it encompasses ideas, norms, values and beliefs - not directly observable, but expressed through behaviours resulting thereof (Uphoff, 2000; Grootaert and van Bastelaer, 2002; Islam et al. 2006). "These two categories of social capital are highly interdependent, as each form contributes to the other" (Uphoff, 2000, p. 220). Namely,

forms of structural social capital are influenced by prior experience since precedents affect expectations about how future behaviour will be rewarded, materially or non-materially." (Uphoff, 2000, p. 229). Also, Isham (2002) states that a long-lasting experience in collective action makes it easier for the group to engage in further initiatives and Putnam (2000) proves that volunteering in one area of life increases the chances of volunteering in another one. 
Social capital is created by social interaction and participation in group and social network actions; it may also be the effect of external interactions initiated for other goals (Beugelsdijk, Smulders, 2003; Grootaert, 1998; Laschewski, 2009). Krishna and Uphoff (2002) claim that social capital is dependent on historical background; thus, it may not be developed in a short time. Simultaneously, Putnam (2000) believes that social capital can be rebuilt just within one or several decades. The two claims above seem mutually exclusive, but only apparently. One could imagine a situation in which a certain group has a high level of cognitive social capital (e.g. common norms and beliefs), but it practically lacks structural social capital (organizations and formal or informal cooperation). In such situations, the second one may be developed in a relatively short time, under the condition that the community shares common values.

As a comparison, a lack of cognitive social capital brings much graver consequences, as "roles, rules, procedures, and precedents can operate only if sets of individuals agree on them" (Krishna, Uphoff 2002, p. 115). This is in line with the intuitive belief that people who do not trust each other and follow different norms and values will not change their way of operating in just a few years. Moreover, the creation of mutual trust and common attitudes, values and norms take a long time, while they can be destroyed in a moment (Svendsen, Svendsen, 2004; Bartkowski, 2003; Uphoff, 2000).

While many researchers claim that it is practically impossible to influence the creation of social capital top-down (Laschewski 2009), it is worth noting that in light of research, "social capital does not exist in a political vacuum and [...] the nature and extent of the interactions between communities and institutions hold the key to understanding the prospects for development in a given society" (Woolcock, Narayan, 2000, p. 243). Some behaviour of leaders or authorities may strengthen or weaken social capital (Uphoff, 2000).

One should also note the already commonly used discernment between the types of social capital depending on the group it relates to. Bonding relates to persons who are similar and thus easy to trust; bridging refers to persons that differ from one another (Bebbington, Carroll, 2002; Beugelsdijk, Smulders, 2003; Islam et al. 2006).

Combining the concepts of bonding and bridging social capital with structural and cognitive social capital results in the creation of a matrix presented in Table 1. As it shows, both bonding and bridging social capital can incorporate cognitive and structural social capital. For a particular study, such matrix should be filled in with more detailed indicators.

Tab 1. A matrix of bonding vs bridging social capital and cognitive vs structural social capital. Source: own elaboration

\begin{tabular}{|l|l|l|}
\hline & Bonding social capital & Bridging social capital \\
\hline Cognitive social capital & $\begin{array}{l}\text { Trust and norms shared with people } \\
\text { of similar characteristics }\end{array}$ & $\begin{array}{l}\text { Trust and norms shared with people } \\
\text { of differing characteristics }\end{array}$ \\
\hline Structural social capital & $\begin{array}{l}\text { Networking with people of similar } \\
\text { characteristics }\end{array}$ & $\begin{array}{l}\text { Networking with people of differing } \\
\text { characteristics }\end{array}$ \\
\hline
\end{tabular}

In this paper, the author assumes that residents of one village may develop bridging social capital, because of the differences in age, education and wealth. According to statistical analyses, bonding social capital in the conditions of Polish villages refers to the closest neighbours and relatives living in the same village (Kłoczko-Gajewska, 2016).

Bridging social capital constitutes bridging structural social capital and bridging cognitive social capital. As for the former, its level is measured by observed in a village membership of its residents in organisations, frequency and variety of their collective actions (for common good and mutual help), and socialising. The latter consists of cultivating traditions, willingness to act together, emotional engagement in common issues, and trust towards other people within the village.

Bonding social capital will not be elaborated further in this paper, so the indicators were not prepared. Also, the category of institutional social capital will be used, understood as the ability 
to communicate with external organizations, commune authorities etc. (Woolcock and Narayan, 2000).

\section{Reducing the number of rural schools in Poland - background information}

Similar to other European countries, Poland has experienced a dwindling trend regarding the number of primary schools, resulting from demographical factors, among others. In the 1998/1999 school year to the 2001/2002 school year, this phenomenon increased in momentum, and the number of rural schools decreased by one-fifth (Chart 1.). It was an effect of a large reform, transforming the 8th-grade primary schools into 6th-grade ones (Domalewski, 2001). The shortening of the number of years spent in primary schools as well as demographical changes resulted in a decline in the number of pupils by $40 \%$ within just four years. The same reform transferred the obligation of financing primary school education from the state government to communes (supported by a state subsidy) (Domalewski, 2006); the state funding depended on the pupil headcount, whilst the costs of school operation were also dependent on other factors (e.g., the pay of teachers depending on their professional advancement level, costs of heating and cleaning, etc.). Similar to Hungary, (Kovacs, 2012, p. 111) „[t]he smaller the village (and its school), the larger [was] the gap between real maintenance costs and state subsidies". It resulted in the closure of a large number of small rural schools (Domalewski, 2006). The decisions on the number and location of the schools are made exclusively by the commune self-governments, while state institutions have only an advisory voice.

It should be noted that in Poland, a village does not have a legal personality, and therefore cannot own any property. For this reason, public buildings in villages, even those built by the villagers as a voluntary community action, are the property of the commune. In effect, after a school closed down, further use of school buildings, often erected with the labour and money of village residents, was at the discretion of community authorities, who did not always take the opinion of the villagers into account (Jakubowski, Kozińska-Bałdyga, 2005).

In some cases, parents of children attending these schools decided to protest against the decisions. Protests in Poland have a long tradition, from those organized against the socialist authorities, to those directed against the decisions of democratically elected governments or forcing the authorities to take some action. In the beginning of the 1990s they became an institutionalized form of communication with the authorities (Foryś, Gorlach, 2002). In some villages, the parents did not stop at organizing protests, but, using the help of specialists from outside of the village, they decided to establish associations that took over the management of those schools from the local authorities. The lower costs of operating the schools managed in this way is a result of many factors, including the volunteer work of parents and more prudence in financial matters resulting from better supervision from the parents than from the local government (Jakubowski, Kozińska-Bałdyga, 2005). 


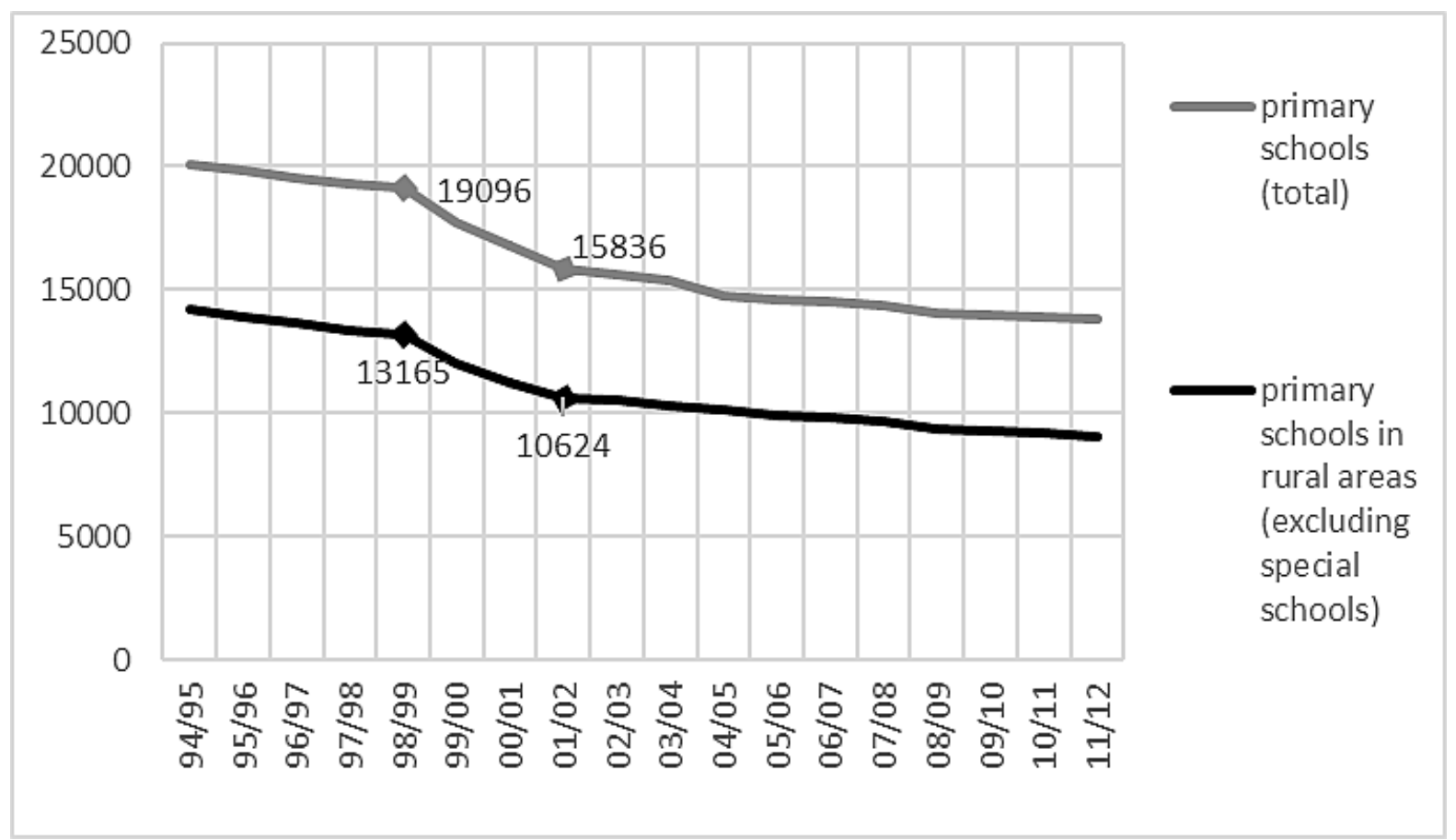

Fig 1. Number of primary schools in Poland (including in rural areas), school years from 1994/1995 to $2011 / 2012$. Source: own work, based on a series of publications of the Polish Central Statistical Office "Education in the school year ..." from 1994/1995 to 2011/2012

\section{Materials and methods}

The author of this paper posed a question: in north-eastern Poland, in 2000, what was the impact of school closures (despite the protests of parents) on the level of social capital observed among the residents of four affected villages?

The research was carried out in two phases: in 2004 and 2016. The units of analysis were local communities in villages where protests were organized in defence of schools. The selected method of study was a comparative analysis with the use of multiple-case studies. According to Yin (2002, p. 10) "case studies, like experiments, are generalizable to theoretical propositions and not to populations", thus the results of this study can be generalised to other villages if they share similar characteristics and face a similar problem. A case study is recommended, among others, to conduct studies on community sociology and neighbourhoods, where the context is important (Yin, 2002), because "the case study allows an investigation to retain the holistic and meaningful characteristics of real-life events" (Laschewski, 2009, p. 106). "[M]ultisite qualitative studies address the same research question in a number of settings using similar data collection and analysis procedures in each setting. They consciously seek to permit cross-site comparison without necessarily sacrificing within-site understanding" (Herriott and Firestone, 1983 , p. 14). For instance, case studies were used in many research projects carried in Norway in 1990s while analysing rural schools embeddedness in local communities (local curricula, schools as local cultural centres and other issues) (Kvalsund, 2019) and in research on schoolcommunity partnerships in the USA (Zuckerman 2019).

Yin (2002) proposes one to carefully select the units of study during the planning of multiplecase studies to enable the study to either predict similar results, or "produce contrasting results but for predictable reason" (Yin, 2002, p. 46). In light of the above, the decision was made to study two villages where the schools were closed and two where the schools were saved while in each of the villages, the protests had to be organized in defence of the school. It was deemed that due to the similarity of the units of study (ethnically and culturally homogeneous villages located in the same region), two cases of each should be sufficient - on the assumption that "when external conditions are not thought to produce much variation in the phenomenon being studied, a smaller number of theoretical replications is needed" (Yin, 2002, p. 50). 
The first part of the study was carried out in the spring of 2004. At the beginning it was necessary to obtain a list of primary schools from the regional education authority (Podlaskie Kuratorium Oświaty) in the Podlaskie region that were closed, or changed management, in 2000. Then a list of schools, where in the year 2000 protests were organized in defence of the school against closure, was prepared. To find these villages, an analysis of the local weekly newspaper "Gazeta Współczesna" was conducted. After reading every edition issued in the year 2000, a list of nine villages where protests were strong enough to be mentioned in the press was created. The next stage was the selection of four villages for further analysis: two which failed, i.e. schools were closed despite the protests, and two which saved their schools. It was done in the following way: one of the schools that was saved was managed by a private individual, three by an association (one of them was to be closed in 2004), and one was still managed by the local authorities. For further analysis, two villages where schools were managed by an association were chosen; the one that was to be closed soon was excluded. Two villages out of the six that failed were chosen in the following way: one village from the same commune as one previously chosen village that succeeded, to keep all external conditions possibly similar. The second one was chosen because it was easily accessible. This resulted in a sample of four villages placed in three communes belonging to one region.

As suggested by Herriott and Firestone (1983), in order to minimize the risk that cross-site similarities and differences will be the effect of differences in methodology or research bias, the same data collection methods and definitions were used in all the villages, and the interviews were carried out by the same researcher. In four selected villages, the researcher conducted semi-structured reviews with local leaders and office workers to acquire rich and indepth information on the following topics: social activeness and the spirit of unity of village residents before the protests against closing the schools began, forms of protests, activeness after their success or failure, and the role of school in the village (both in the past and currently). All interviews were conducted face-to-face. Semi-structured face-to-face interviews in order to establish relationship between rural schools and local communities were carried out also by Karlberg-Granlund (2019). Similarly, Kramer (2019) used expert interviews while doing research on small rural schools in Germany and Austria, and Buzzard (2016) used semi-structured interviews with a small group of people to assess the impact of school closures on local communities.

The first round of interviews took place in spring 2004. In all of the villages, the administrators [sołtys ${ }^{2}$ ] were interviewed. In some villages, deputies to the commune or district councils were interviewed, as well as workers of local offices, local priests, and headmistresses of the schools, to ensure multiple sources of evidence, according to the guidelines set out by Yin (2002). The types of people differed among the villages, as not all the villages had schools, not all communes had libraries, and some people were not accessible. More detailed description of the interviewees is given in the table 2.

In the first round, the respondents knew that the research concerned the village residents' activeness before and after the protests against the closure of the school. That was the moment when they could somehow describe the activeness a bit in the way they wanted to be seen. Majority of those interviews was audiotaped, and in case when the interlocutor objected to audio recording, notes were taken during the interview. As all the interviews were performed by the same researcher, it was also possible to record such nuances as to the mood of the interviewee and the condition of the school and the village, which were noted down directly after the interview. The questions were open-ended, for example: Are there any formally registered organisations in this village, such as Rural Women's Circle or Farmers' Circle? Were there such organisations active in earlier times? Do people in this village cooperate with each other, work jointly? Do people in general help each other, trust each other? Are there any local customs? Are there any meeting held in the school building? Could you describe the situation in the village when the school was supposed to be closed? What did you do to prevent it?

\footnotetext{
${ }^{2}$ A village administrator is a kind of village head, but with much less power than mayors in cities - in commune council meetings, the village administrators have only the right to voice opinions (Jakubowski and Kozińska-Bałdyga, 2005).
} 
Tab 2. People interviewed in the villages in 2004 and 2016 ( $F-$ female, $M$ - male). Source: own elaboration

\begin{tabular}{|c|c|c|c|}
\hline Village L. & Village K.-P. & Village B. & Village S.G. \\
\hline \multicolumn{4}{|c|}{2004} \\
\hline $\begin{array}{l}\text { village administrator }(\mathrm{M})+ \\
\text { some remarks from his } \\
\text { adult son }(\mathrm{M})^{*}\end{array}$ & village administrator (M) & village administrator (M) & village administrator (M) \\
\hline $\begin{array}{l}\text { deputy to the district } \\
\text { council }(F)+\text { some } \\
\text { remarks from her adult } \\
\text { son }(M)^{*}\end{array}$ & $\begin{array}{l}\text { worker of the commune } \\
\text { office }(M)\end{array}$ & $\begin{array}{l}\text { worker of the commune } \\
\text { office }(M)\end{array}$ & $\begin{array}{l}\text { worker of the commune } \\
\text { office (M) }\end{array}$ \\
\hline \multirow[t]{3}{*}{ school headmistress $(F)$} & school headmistress $(F)$ & $\begin{array}{l}\text { former village } \\
\text { administrator (M) }\end{array}$ & local priest (M) \\
\hline & local priest (M) & $\begin{array}{l}\text { former deputy to the } \\
\text { commune council (M) }\end{array}$ & \\
\hline & $\begin{array}{l}\text { representative of the } \\
\text { Centre of Educational } \\
\text { Initiatives in Warsaw that } \\
\text { mediated during the } \\
\text { conflict }(F)\end{array}$ & & \\
\hline \multicolumn{4}{|c|}{2016} \\
\hline school headmistress $(F)$ & school headmistress (F) & village administrator (M) & village administrator (M) \\
\hline $\begin{array}{l}\text { deputy to the community } \\
\text { council (M) }\end{array}$ & community librarian (F) & village shop assistant (F) & community librarian (F) \\
\hline $\begin{array}{l}\text { president of the NGO that } \\
\text { manages the school }(F)\end{array}$ & $\begin{array}{l}\text { president of the NGO that } \\
\text { manages the school }(F)\end{array}$ & $\begin{array}{l}\text { an old lady working in her } \\
\text { garden in the village }(F)\end{array}$ & $\begin{array}{l}\text { worker of the } \\
\text { environmental education } \\
\text { centre placed in former } \\
\text { school (F) }\end{array}$ \\
\hline
\end{tabular}

*The remarks were given when the son was accidentally passing by the room in which the interview was carried out.

It is interesting that in the first round of the interviews, the respondents voluntarily gave many additional comments also on other issues, such as the quality of work of local authorities, the schools operating in the neighbourhood, and others.

The second round of interviews took place in the spring of 2016. The same villages were visited again and the interviews were done, sometimes with the same persons, and sometimes with others (a new village administrator, a new school headmistress, a local librarian). The topic of the interviews was the social activity of the village residents between 2004 and 2016 and how the school building was utilized. To avoid possible bias, the interviewees were not told that the research was aimed at looking for the connection between school closure and social activeness. Some of the questions were formulated as follows: Do people in your village cooperate with each other? Are there any social events organised? Are there any formally registered organisations active in the village? Are there any local customs?

It is worth noting that after 12 years, it was much more difficult to arrange a meeting: people had less time, sometimes they were absent during the interview days, some displayed overt distrust. For instance, one of the school headmistresses agreed to give an interview only after the request of the researcher was backed by the chairman of the NGO that managed the school. In 2004, all the interviews took place in a friendly atmosphere, as though it were a relaxed, friendly meeting. In 2016 , everything was shorter and more official. Notes were taken by hand.

The data on the number of village residents and of school-aged children was acquired by e-mail from relevant commune offices. 


\section{The results}

The results of field research were ordered beginning from the more successful villages (two that saved the school and kept more or less activeness) to the less successful ones (failed to keep the school, and the last one being particularly affected). All the information, excluding the number of inhabitants and the names of the districts, comes from the interviews.

\subsection{Village L.: the rich and successful}

Village L. is situated in the Łomża district. In 2004, the village was inhabited by 168 people (including 20 children aged between 7 and 15). There was only one officially registered organisation: the local chapter of the association "Edukator", managing the school. Previously there used to be a Rural Women's Club, but its operation ceased circa 1999. There was no community centre or shop. The only public buildings were: the school and a point for collecting milk from farmers. The village was rather wealthy. According to both the son of the village administrator and the school headmistress, the village residents were rather educated. Migration abroad was not very popular, sometimes people moved to nearby towns or other villages. The village administrator and the adult son of the deputy to the district council spoke with disrespect about those who had chosen to emigrate.

The citizens of $L$. have always been very active in many fields (organising the collection of waste, dealing with minor repairs at school, helping neighbours in need such as serious illness or fire, etc.). However, they could also be critical about their neighbours (like those who tried out new technologies). Nevertheless, people living in village L. were said to keep together.

They have been concerned with education for generations. The first written mention of teaching in this village comes from 1905. They built their schools by themselves - in the late 1940s a wooden building, in 1962 a new one. The school was supposed to be closed several times, for different reasons. Each time a group of parents would go and protest against the decision. Under communism they would go to Warsaw or to a local committee of Polish United Worker's Party (PZPR), and later somewhere else. As the deputy to the district council says, they knew that they had to go somewhere by themselves to affect the change of the decision, because nobody would come to their place to see what the situation was. She also mentioned that each time they needed help, they met somebody friendly who understood their problems.

In 2000, the school was again threatened with closure. The children would have to go by bus to a distant school where there were many classes and hundreds of pupils. Moreover, the school was the only meeting place, and a place of work for the teachers. To protest against the decision, they started writing official letters. Many parents and other citizens (who hoped that their grandchildren would attend this school) went to a session of the commune council to state their arguments. Additionally, people used their personal connections in offices (they continued later to find sponsors and donors). They did not have to organise any strikes or demonstrations - it was a peaceful protest. Meanwhile, one of the parents heard on the radio about the Centre of Educational Initiatives in Warsaw that objected to the closure of small local schools, so they called the organisation. The head of the organisation came to the village and suggested setting up a local association that would manage the school. The commune council members consented, although they were not sure what would it all look like, because it was the first school in a region that was supposed to be managed by an association. At the same time there were a series of articles about the school published in a local weekly, "Gazeta Współczesna", and its editor visited the school. Probably, these articles informed people from the association "Edukator", located in the nearest city, that the school would be managed by an association. The president of "Edukator" met with the parents and they agreed that in the village a local chapter of the "Edukator" would be established.

Pursuant to the agreement, from the year 2000 on, parents cleaned the school according to the following scheme: parents work as many weeks as many children they have attending the school, and they bring their own cleaning supplies. They also took care of the school grounds - cutting the grass, planting trees, and any other work that needed to be done. When there was a shortage of money for renovating the school roof, parents collected it in the village. 
If there was a need to visit a donor or a bank, they would do it. They have also improved the school sports field: installed new football goals and added basketball nets. The sports field was not only used by the schoolchildren, but also by older children and even adults. Boys took part in championships organised by the administration of their commune, children also took part in other competitions - not only organised by education authorities, but also by the local parish. Parents would drive the children to places where competitions took place.

In 2004, the school was a real social centre of the village. Firstly, it organised discos for the children at least once a month, open for children attending the school as well as graduates. At the end of January, there was a party for the whole village: schoolchildren prepared songs and poems, and there were gifts for the children, handed out by Santa Claus. Each year, there was also a carnival ball.

Secondly, there were courses for farmers held in the school. The school headmistress searched on the Internet for information about new courses organised by the Agency of Restructurisation and Modernisation of Agriculture [Agencja Restrykturyzacji i Modernizacji Rolnictwa]. The courses were held in the afternoons and sometimes during weekends. In the last course, they learned computer accounting for farming purposes and preparing for EU accession. Approximately, half of the citizens of $L$. attended the courses - some even every year - and there were many participants from other villages (even from different communes). The courses were also a good occasion for meetings - during the breaks, they had tea or coffee and talked. The money provided by the Agency for the courses was spent on paying for the lecturers and for infrastructure: new chairs, computers, oil for the heating, insurance of the building and equipment, etc. The school was very well equipped: two old computers given some time ago by donors, eight modern computers with access to the Internet, two photocopying machines (one of them portable), and a projector. The computers were used by all the villagers.

The third reason why the school was the centre of the village was the way meetings were organised. If there was a need or an idea to be discussed, a person who wanted to organise something informed the school headmistress. She would write the information on pieces of paper which were distributed by the children. If too few people came to school for such a meeting, it was clear that there was no interest in the initiative. However, it was enough if there were just several enthusiasts to encourage other people to get involved. In this village there were four main leaders (according to the school headmistress): the deputy to the district council (second tenure), the president of the parents' council, the deputy to the commune council (second tenure), and the school headmistress.

In the village, there is a local custom called "Gypsies" [Cygany]: at the end of carnival children dress up in a strange and funny way and go from house to house, singing and dancing. People give them sweets and sometimes a little money. When the village started getting wealthier, some people did not like this tradition, as taking money was seen as a beggarly custom. But later people who moved to towns came to the village, especially to show it to their children who were brought up outside the village. The next custom is that at the end of the harvest, people take cereal wreaths to the church. As for other traditions, historically, women used to meet in each other's houses for common work, and later they met to drink coffee and gossip - although less frequently, as watching TV was the main leisure activity.

In 2016, the village was inhabited by 132 people, including 13 children aged between 7 and 15 . The Rural Women's Club was still in existence, but its activities were on the wane. A shop was set up in the village, but the milk collection centre closed down. The meetings, get-togethers and trainings were still organized in the biggest school room, sometimes also in the community centre in the next village. The school was still the social centre of the village and the calls to meetings were distributed by children. The building of the school was well kept and maintained. Some of the parents voluntarily offered help to the school, some took less interest than in previous years. The school still housed events, e.g. Grandfather's and Grandmother's Day, but there were fewer events than before 2004. Younger children still upheld the tradition of "Gypsies", but the older ones did not participate. The courses for farmers were still organized in the school, but not as frequently, due to smaller grants from the Agency. A commune council member stated that in fact outside of the school, there was no activity, and the village meetings 
were organized in the village administrator's house. Common festivities, such as the New Year's Eve, used to be organized in the school, now they were moved to community centres of neighbouring villages. When an outdoor fest was organized, twice there were no volunteers to help. No envy or maliciousness was noted in the village, but people stopped meeting on the benches outside their houses - they prefer to watch TV or use a computer.

\subsection{Village K.-P.: the poor and successful}

Village K.-P. is situated in the Białystok district. In 2004, there were 222 inhabitants (including 44 children aged 7-15), but some of them stayed in larger cities to continue their education, and some moved to work abroad - mostly to the USA and Germany. As the village administrator said, most of the young people continued their education after completing the required years of schools. They were rather poor, due to small plots of land and very weak soil. There were no official organisations registered in the village, only a prayer club, organising meetings every Sunday. Many years ago, there was also the Rural Women's Club. There was a small shop with food and other basic goods (managed by the village administrator), the school, and a community centre - the latter not in use because it needed serious renovation.

People living in this village have always been rather active, and in 1995, they raised the money for building the school. When the commune authorities decided to close the school, they started to write official letters and protests, and they also informed the mass media about it (in 2004, the office workers claimed that there were mostly teachers, not parents, who protested). Some of the parents heard about the school in L., which was the first to be taken over by an association. After a struggle between the village residents and the authorities, the external mediation was used. Thanks to it the school was saved.

Similarly, as in L., the parents helped in maintaining the school, although after the first year their engagement slightly declined. The school became the centre of village life. There were no other events in the village except for those organised by the school. Nevertheless, the local office workers stated that parents only cleaned the school, and that they did not take any initiative in any other field, waiting for the "Edukator's" assistance. However, at the same time, the workers complained about the villagers' frequent requests for public co-financing of their initiatives or investments, which were brought up at almost every session of the commune council.

According to the village administrator, the village residents helped their closest friends or families, but did not form a community. Even though they were eager to fix the church, they did not come to an agreement on improving the road and renovating the community centre. On the other hand, the priest described them as friendly and good-hearted, despite some conflicts between families. According to his observations these people did not cooperate, but when there was a common problem or threat, they were able to unify and do something together - like in the case of the school.

In 2016, the village numbered 214 inhabitants (27 children aged 7-15). Many of the young people emigrated abroad, but some of them built houses in the village. The prayer club was still active. For some time, there was an association in the village, but it was dissolved in 2014. The community centre was still not in use, and the shop ceased activity - but the school shop was operating. The parents of the children still helped in the school, but the voluntary shiftbased cleaning was abandoned and a cleaner was hired. The number of courses for adults decreased, as the Agency had a smaller range of offers. The school provided rooms for meetings and rented them out for private events. If there was an initiative to do something for the common good, majority of the people joined. According to the community librarian, the village was rather team-oriented and cooperative. The president of the "Educator" added that the community authorities cooperated constructively with the association in the development of the school (e.g., financing of repairs). 


\subsection{Village B.: the rich and unsuccessful (?)}

Village B. is situated in the Augustów district. In 2004, it had 161 inhabitants, including 42 children (20 aged 7-15) and in about 30 households. It is a rich village; its residents own modern agricultural machinery and are fairly educated. They rarely emigrate.

They have always been active: there was a shop and a community centre, both situated in a building erected by the villagers. The former headmistress of the school claimed that it was the first village in the commune where telephones were installed in the houses, they were also quick to organise water pipes and to build an asphalt road. They have always been "politically strong" - several citizens were members of political parties, and one of them was the president of a supervisory council in a dairy cooperative. Workers from the commune office saw them as hardworking, making proper investments, and keeping together.

The school was initially situated in an old building, modernised in the mid-1990s. As for the parents, they were very active and engaged in school life: helping in organising feasts and small repairs. Children organised theatre plays for Christmas, there were also parties with an orchestra. Villagers wanted to build a new, modern building for their school, and in 19971998 they organised dancing feasts with the chief officer and deputies to the commune council to persuade them of the idea.

In the year 2000, the local administration decided to close the school. People inhabiting the village started protesting against it; they came to meetings of the commune council, organised meetings at the school, and they even took legal proceedings against the decision in the Supreme Administrative Court and Podlaskie Kuratorium Oświaty. The decision was officially confirmed and said to be legal, and the school was closed. There was no proposal to create an association to manage the school, as the idea was very new and not popular yet.

In 2004, when asked, the present village administrator, the former village administrator and the former deputy to the commune council talked about the protest with contempt, as something that happened a long time ago and was not very important. There were not as many problems as they had expected: the bus used to come regularly to take the children to their new school, most of the teachers found jobs in other schools. And last but not the least, the building was not empty - there was a sports club situated in it, the sports field was clean and tidy, however there were no attempts to renew the building itself. The pupils' sport club was created in the school during the last few years before the closure. When the authorities of this commune were closing the schools, they were trying to make the buildings serve the needs of the village (at least this is what the chief officer claimed), because most of them were built with the help of villagers.

There were many events in the village, especially in the summer. They hosted a football tournament within the commune and took part in other competitions, such as a folk one (knowledge of herbs, baking, decorating, saw-cutting, etc.) in which they took third place in the region. Apart from competitions, people took part in courses for farmers organised by the Agency of Restructurisation and Modernisation of Agriculture and other courses. The courses were held in the school, community centre, or in the village administrator's house. Formally, the Rural Women's Club was registered, but in 2004, it existed only formally. The citizens kept together and helped each other. There were also some local customs - on Christmas children used to go from house to house "with a star", singing Christmas carols, and on Easter they used to go with painted eggs.

They appeared quite satisfied with their situation, however, the former village administrator said that it was more difficult to make people active than it was when the school was working. When parents were meeting regularly at schools (to learn about their children's grades), they had time to discuss and organise various events - every meeting resulted in new ideas. Each year, they were doing repairs to the school, because it served their children. After the school closure when the meetings were organised by the village administrator - less people used to come and there were less ideas raised.

In 2016, the village was inhabited by 175 people, including 18 children aged 7 to 15 . The Rural Women's Club was already dissolved, and the prayer club was "small and feeble". The shop was still there (although it was planned to be shut down), the community centre was used only 
for village gatherings. The farmer courses were organized in another village. Around 2010, the former school building was bought by a private person from the city for a summer house. A part of the school yard was sold together with the school and served as a garden, and another part was still used by the village - once a year, before the fire brigade display, the village residents mow the lawn there. Football matches were sometimes played there, but not frequently. Young people organized bonfires, but essentially, they preferred to spend time on the Internet. If there was a need for a meeting, either the village administrator called up the villagers, or the information was passed down from door to door (on a piece of paper or by phone). The meetings were almost non-existent, everyone lived their separate lives, busy with work or private matters. Only around 2010 did the village residents jointly put a layer of gravel on the local road. Older people sometimes volunteered for community activities, younger ones never did. There were no common events, no leaders, even though the village kept together.

\subsection{Village S.G.: rather poor and unsuccessful}

Village S.G. is situated in the same commune as village K.-P., described earlier. In 2004, it was inhabited by 175 people, including 28 children aged between 7 and 15 . The soil in the village fields is weak compared to average Polish conditions, but still the best in their area. Formerly, it was a village of poor gentry - they were not richer than peasants, but they had many more political and civil rights before World War I. Their priest described them as very ambitious, with a strong sense of honour. He also said that they helped each other often. Quite a lot of people emigrated, mostly to the United States, and they rarely came back.

People in this village used to be active. There were dancing parties organised, and they had a similar custom as in village L., called "Gypsies". Both of these traditions disappeared the village administrator claimed that there were not enough young people, and if they were, they went to towns to continue their education. The citizens of S.G. built a local cooperative shop by themselves. Some time ago, it was sold by commune authorities to a private person, and although in 2004, it worked well, they were a bit disappointed that their common work did not serve the common good as much as it could.

In 1993, they built a school, because until then, children were taught in private houses. All the villagers participated in building the school, it was very nice and modern. In 2000, local authorities decided to close the school. Parents started to protest - among others they went to Podlaskie Kuratorium Oświaty and took part in a debate on TV. They also took part in a discussion with a representative of the Ministry of Education and local chief officer, but (according to the priest) the deputy to the commune council coming from the village offended the authorities. At that time, local authorities wanted to close down four out of six village schools in their commune, and two of the buildings (in S.G., and K.-P., mentioned earlier) were the best, most modern, and suitable for teaching, according to what regional educational authorities said. Despite these facts, the commune authorities decided to close them down, and at the same time expand the building in their own village (Które... 2000). What vexed the village administrator the most was the fact that the representatives of the commune council did not even come to see the building - they came only after passing the decision. There was no idea of creating an association, because this way of managing the school was not known at that time.

In 2004, the building was empty. The village administrator suggested to the local chief officer that "something for tourists" should be situated there, but this idea was not taken any further. There was a burglary in the school, the locks were destroyed, and the interiors were demolished. Children went to the other school by bus - so far, the bus used to go regularly, but in the winter, the travel took quite long, and the bus was in bad shape. The village administrator was unhappy to see that the school which was functioning in another village was very crowded and the authorities planned to make it larger, while the school in his village was getting devastated. Almost all the teachers found jobs in other schools working in the area.

Besides the school and a local shop, in village S.G., there used to be a local fire station. However, they did not pay the membership fee to the commune authorities, so the electricity was cut off, the equipment was taken by local authorities and the building in 2004 was emptied. 
There was no community centre in the village, and all the meetings took place in village administrator's house. Some people took part in courses for farmers organised by other schools.

Generally speaking, in 2004, the village administrator had a feeling of loss; the school and the fire station were abandoned, nothing was created in their place, and the shop was sold to a private owner. The people, who used to be very active, refused to take any common action. They were disappointed and dispirited.

In 2016, the village had 135 inhabitants, including 15 children aged 7 to 15 . The former fire station stood abandoned and devastated, but a milk collection point appeared. The former school building housed the environmental education centre, managed by the commune, due to which the building was in good condition, but the village administrator did not feel that it had any benefit for the village. No other registered organizations operated there. The administrator explained it was due to having a small number of villagers (but it should be noted that the population of village L. was similar, and the activity was retained) and that everybody was very busy. Moreover, there was a lack of leadership, no activities were organized (the young preferred to surf the Internet). There were no courses organized by the Agency - nobody was interested in participation. The administrator said that the meetings were organized either at the administrator's house or in a pavilion, while the employees of the education centre claimed that they sometimes provided the rooms to the village residents for meetings. At any rate, there was no feeling of community between the employees of the centre and the villagers.

The village residents were disillusioned towards joint activity, young people moved out to cities, which resulted in 11 out of 43 houses in the village standing empty. The commune authorities withdrew the village council fund, the road still had no surface despite pleas from the villagers to pave it with asphalt. There was no communal water or sewage service. Power failures led to water shortages. According to the village administrator, it was the most neglected village in the commune. The commune authorities did build a bicycle path with a pavilion, but it served tourists rather than the village residents.

\section{Conclusions and discussion}

This study focused on the long-term effect of school closure on the social capital of village residents. The interviews were performed few years after the school closure and after a further 12 years. The comparison of two villages where the schools were closed and two where the schools were kept allows to capture in the analysis and to partly eliminate the impact on the social capital of more general processes taking place during that period in rural communities. The main findings of the research are summarised in Table 3 . The level of social capital is described as high, fairly high, moderate or low basing on the declared by the interviewees number and variety of common actions (see (Autti, Hyry-Beihammer, 2014) as well as the ability to properly intervene in the authorities to defend the school.

As we could see, the plans of schools' closures were met with protests both through formal channels and by demonstrations, talking to the press etc. The protests increased the feeling of community, which later waned as the time passed since their ending - similarly to the New Zealand school case (Witten et al., 2001). 
Tab 3. Summary of information from the multiple-case study. Source: own research

\begin{tabular}{|c|c|c|c|c|c|}
\hline & & village $L$. & village K.-P. & village $B$. & village S.G. \\
\hline \multirow{2}{*}{$\begin{array}{l}\text { Number of } \\
\text { inhabitants }\end{array}$} & 2004 & 168 & 222 & 161 & 175 \\
\hline & 2016 & 132 & 214 & 175 & 135 \\
\hline \multirow{2}{*}{$\begin{array}{l}\text { No. of children aged } \\
7 \text { to } 15\end{array}$} & 2004 & 30 & 44 & 20 & 28 \\
\hline & 2016 & 13 & 27 & 18 & 15 \\
\hline \multicolumn{2}{|c|}{$\begin{array}{l}\text { Social capital before the year } \\
2000\end{array}$} & $\begin{array}{l}\text { High (bridging and } \\
\text { institutional) }\end{array}$ & $\begin{array}{l}\text { Fairly high (mainly } \\
\text { bridging) }\end{array}$ & $\begin{array}{l}\text { High (bridging and } \\
\text { institutional) }\end{array}$ & $\begin{array}{l}\text { Fairly high (mainly } \\
\text { bridging) }\end{array}$ \\
\hline \multicolumn{2}{|c|}{$\begin{array}{l}\text { Forms of protests in the year } \\
2000\end{array}$} & Peaceful, formalized & $\begin{array}{l}\text { Initially peaceful and } \\
\text { formalized, later also } \\
\text { violent }\end{array}$ & Peaceful, formalized & $\begin{array}{l}\text { Peaceful, formalized } \\
\text { plus talking to the } \\
\text { press, emotional }\end{array}$ \\
\hline \multicolumn{2}{|l|}{ Protest effect } & School saved & School saved & School closed & School closed \\
\hline \multicolumn{2}{|c|}{$\begin{array}{l}\text { Use of school for community } \\
\text { needs in } 2004\end{array}$} & $\begin{array}{l}\text { Very high (children } \\
\text { and adults) }\end{array}$ & High & $\begin{array}{l}\text { Moderate (more } \\
\text { adults, less children) }\end{array}$ & $\begin{array}{l}\text { None, interior } \\
\text { devastated }\end{array}$ \\
\hline \multicolumn{2}{|c|}{ Social capital 2000-2004 } & High & $\begin{array}{l}\text { Moderate, } \\
\text { concentrated around } \\
\text { the school and the } \\
\text { church }\end{array}$ & $\begin{array}{l}\text { Fairly high } \\
\text { (cognitive maintained, } \\
\text { structural slightly } \\
\text { weakened) }\end{array}$ & Very low \\
\hline \multicolumn{2}{|c|}{$\begin{array}{l}\text { Use of the school building for } \\
\text { community needs in } 2016\end{array}$} & $\begin{array}{l}\text { High (children and } \\
\text { adults) }\end{array}$ & $\begin{array}{l}\text { High (children and } \\
\text { adults) }\end{array}$ & $\begin{array}{l}\text { None (school sold, } \\
\text { minor use of school } \\
\text { football field) }\end{array}$ & $\begin{array}{l}\text { Building used by the } \\
\text { commune, but not } \\
\text { serving the village } \\
\text { residents }\end{array}$ \\
\hline \multicolumn{2}{|c|}{ Social capital 2004-2016 } & Fairly high & $\begin{array}{l}\text { Moderate, } \\
\text { concentrated around } \\
\text { the school and the } \\
\text { church }\end{array}$ & $\begin{array}{l}\text { Moderate } \\
\text { (cognitive maintained, } \\
\text { structural lacking) }\end{array}$ & $\begin{array}{l}\text { Very low, } \\
\text { despondence (low } \\
\text { structural and } \\
\text { cognitive) }\end{array}$ \\
\hline
\end{tabular}

As it was presented above, in all studied villages since the time of protests until 2016, a decrease in structural social capital was noted. Similarly, as described by Putnam (2000), it may be caused by the use of electronic mass-media (TV, the Internet), but also by growing diversification of types of agricultural production which leads to the loss of social ties among farmers (Perepeczko 2009), work overload, and depopulation. However, according to the interviews, this drop was significantly smaller in those communities where the school was saved. The schools, by giving a pretext for informal meetings (e.g. school performances or parent-teacher conferences) facilitated regular contacts between the parents of pupils, which resulted often in ideas of common initiatives. Similar patterns were observed by Witten et al., (2001), Svendsen and Sørensen, (2016), as well as Young (2016). In Denmark, the decrease of community behaviours in rural communities was also noted, and the closure of schools reinforced that trend. It was also observed that losing the place for casual informal meetings, which the school was, decreased social cohesion. Voluntary community work is less popular, especially among the younger generation (Svendsen, Sørensen, 2016). Also Buzzard (2016) noticed the decrease of communal activities after the closure of the schools in the USA, however no comparison was done with the villages where the schools were still operating. The decrease of localised activities after the closure of small rural schools was observed also in Scotland in the second half of $20^{\text {th }}$ century - the scale of the change depended on the remoteness of the village (Young, 2016). Still, it has to be remembered that "where the initial level of social capital is low, the chances that it will grow around a school are slim" (Jakubowski, Kozińska-Bałdyga, 2005, p. 75).

In the village where the school was closed, but the building for some time served the village residents, the structural social capital decreased, but there was no feeling of failure, so people still believed in the need to act together (the cognitive social capital did not change).

In the village where over a few years the commune authorities closed the school and the fire station, and sold the collective shop, a feeling of despondency appeared and held at least until the moment of the second study in 2016. The previously observed norm of common work for the good of the village abruptly disappeared and was not reintroduced after several years. One may conclude that the closure of the school had less impact on the social capital of the people than the general feeling of chagrin and failure arising from the fact that the effort was in vain and 
the authorities ignored the opinion of the locals. This also included the feeling of loss of invested resources (mainly time and work) - similarly to the New Zealand school (Witten et al., 2001).

It is also important how the building is used after its closure - e.g., in Austria, a tendency is observed that the school building further serves the community as a kindergarten or a community centre. This allowed for the reduction of the feeling of disillusionment related to the closure of a school (Kroismayr, 2017). Similar to other studies (Christiaanse, Haartsen, 2017), the residents of the four villages included in the research stressed that it is the only, if not one of the few public places that impact the feeling of vital rural community. Bearing that in mind, local authorities often try to reduce the impact of school closures, both by increasing the attractiveness of the remaining schools (properly organised commuting, school lounges) and by allowing the village inhabitants to use the buildings (Kotarba 2017).

This leads to the next important conclusion: local authorities may influence the level of social capital of village residents. They are not able to create it by themselves in places where such capital is non-existent, but they can devastate it with a decision that ignores the needs and opinions of villagers, or, conversely, maintain it with concordant cooperation. This confirms observations made by Komendera (1996): the activeness of people inhabiting rural areas is possible only if two conditions are satisfied. The first condition is that people have to be eager to self-organise and know how to achieve their goals. The second is that the authorities provide proper help, i.e. well-balanced in means and limitations. Many researchers have long stated that the emergence of social capital requires governments operating "in a fair, transparent, accountable, and trustworthy manner" (Productivity Commission, 2003, p. 77).

One may also note that villages with strong institutional social capital (knowing which institutions to address to secure their interests) have a higher potential to achieve success, which translates into further motivation for joint actions. This means that communities lacking influence and institutional social capital are threatened with entering the vicious circle of powerlessness and despondency.

Finally, we may assume that the lack of common initiatives resulting from the school closures might impact the younger generation that will not be raised in the spirit of community (Puntam (2000) also noted this threat). In the long run it may cause the weakening of the cognitive social capital.

\section{Acknowledgements}

The part of this research carried out in 2004 was done while writing an MA thesis supervised by Prof. Andrzej Rychard.

I would like to thank Jan Kłoczko and Carlos Cruz for helping me to achieve linguistic correctness of this paper.

This research did not receive any specific grant from funding agencies in the public, commercial, or not-for-profit sectors.

\section{Academic references}

[1] Aberg-Bengtsson, L. (2009). The smaller the better? A review of research on small rural schools in Sweden. International Journal of Educational Research 48, 100-108. DOI: 10.1016/j.jijer.2009.02.007.

[2] Bagley, C. \& Hillyard, S. (2014). Rural schools, social capital and the Big Society: a theoretical and empirical exposition. Br. Educ. Res. J. 40(1), 63-78. DOI: $10.1002 /$ berj.3026.

[3] Bebbington, A. J. \& Carroll, T. (2002). Induced social capital and federations of the rural poor. In Grootaert, Ch. \& van Bastelaer, Th., eds., The role of social capital in development. An empirical assessment (pp. 234-278). Cambridge University Press. 
[4] Beugelsdijk, S. \& Smulders, S. (2003). Bridging and bonding social capital: which type is good for economic growth? In ERSA 2003 - 43rd Congress of the European Regional Science Association, Jyväskylä, 2003.

[5] Bourdieu, P. (1986). The forms of capital. In Richardson, J., ed., Handbook of Theory and Research for the Sociology of Education (pp. 241-258). Westport, CT: Greenwood Press.

[6] Bartkowski, J. (2003). Tradycja i polityka. Wpływ tradycji kulturowych polskich regionów na współczesne zachowania społeczne i polityczne. Warszawa: Wyd. Akademickie „ŻAK”.

[7] Buzzard, R. A. (2016). What Every Policy Maker, School Leader, Parent, and Community [PhD theses]. Lewiston: Niagara University.

[8] Christiaanse, S. \& Haartsen, T. (2017). The influence of symbolic and emotional meanings of rural facilities on reactions to closure: The case of the village supermarket. Journal of Rural Studies 54, 326-336. DOI: 10.1016/j.jrurstud.2017.07.005.\&.

[9] Domalewski, J. (2001). Szkoła wiejska wobec zadania rekompozycji struktury społecznej. Prz. Socjol., t. L/1. Przegląd Socjologiczny/Sociological Review 50/1, pp. 99-122.

[10] Domalewski, J. (2006). Szkoła wiejska jako czynnik i jako rezultat rozwoju lokalnego. In: Styk, J., Łacek, M. \& Niczyporuk, D., eds., Stare i nowe struktury społeczne, tom VI. Endogeniczne czynniki rozwoju obszarów wiejskich. Lublin: Wydawniczstwo UMCS.

[11] Domalewski, J. (2010). Edukacja a procesy rozwoju obszarów wiejskich. In: Stanny, M. \& Drygas, M., eds., Przestrzenne, społeczno-ekonomiczne zróżnicowanie obszarów wiejskich w Polsce. Problemy i perspektywy rozwoju. Warszawa: IRWiR (pp. 181-201).

[12] Dwyer, J. (2016). New approaches to revitalise rural economies and communities reflections of a policy analyst. European Countryside 8(2), 175-182. DOI: 10.1515/euco2016-0014.

[13] Foryś, G. \& Gorlach, K. (2002). The Dynamics of Polish Peasant Protests under PostCommunism. Eastern European Countryside 8, 47-65.

[14] Grootaert, C. (1998). Social capital: the missing link? Social Capital Initiative, [Working Paper No3]. Washington D.C, World Bank.

[15] Grootaert, C. \& van Bastelaer, Th. (2002). Introduction and overview. In Grootaert, Ch. \& van Bastelaer, Th., eds, The role of social capital in development. An empirical assessment (pp. 1-16), Cambridge University Press. DOI: 10.1017/CBO9780511492600.

[16] Guðmundsson, G. \& Mikiewicz, P. (2012). The concept of social capital and its usage in educational studies. Studia Edukacyjne 22, 55-80.

[17] Hargreaves, L. M. (2009). Respect and responsibility: Review of research on small rural schools in England. International Journal of Educational Research 48, 117-128. DOI: 10.1016/j.jijer.2009.02.004.

[18] Hargreaves, L., Kvalsund, R. \& Galton, M. (2009). Reviews of research on rural schools and their communities in British and Nordic countries: Analytical perspectives and cultural meaning. International Journal of Educational Research 48, 80-88. DOI: 10.1016/j.jijer.2009.02.001.

[19] Herriott, R. E. \& Firestone, W. A. (1983). Multisite Qualitative Policy Research: Optimizing Description. Educational Researcher. February, 14-19. DOI: 10.3102/0013189X012002014.

[20] Isham, J. (2002). Can investments in social capital improve local and environmental outcomes? A cost-benefit framework to assess the policy options. In Isham, J., Kelly, T. \& Ramaswamy, S., eds., Social capital and economic development. Well-being in developing countries (pp. 3-17). Cheltenham: Edward Elgar Pub. DOI: $10.4337 / 9781781950388.00020$. 
[21] Islam, M. K., Merlo, J., Kawachi, I., Lindström, M. \& Gerdtham, U.-G. (2006). Social capital and health: Does egalitarianism matter? A literature review. International Journal of Equity in Health 5, 3. DOI: 10.1186/1475-9276-5-3.

[22] Jakubowski, M. \& Kozińska-Bałdyga, A. (2005). Małe szkoły - pomysł na wybrane problem wiejskiej oświaty w Polsce. Wieś i Rolnicztwo 3(128), 59-79.

[23] Jaros, A., Margiela, D. \& Mikiewicz, P. (2009). Niwelowanie nierówności poprzez wzmacnianie kapitału społecznego: historia pewnego projektu. In MęczkowskaChristiansen, A. \& Mikiewicz, P., eds., Idee -diagnozy -nadzieje: szkoła polska a idee równości (pp. 243-263). Wrocław: Wydawnictwo Naukowe Dolnośląskiej Szkoły Wyższej.

[24] Kalaoja, E. \& Pietarinen, J. (2009). Small rural primary schools in Finland: A pedagogically valuable part of the school network. International Journal of Educational Research 48, 109116. DOI: 10.1016/j.jer.2009.02.003.

[25] Karlberg-Granlund, G. (2019). Exploring the challenge of working in a small school and community: Uncovering hidden tensions. Journal of Rural Studies 72, 293-305. DOI: $10.1016 /$ j.jrurstud.2019.10.017.

[26] Kłoczko-Gajewska, A. (2016). Kapitał społeczny a efekty gospodarowania rodzinnych gospodarstw rolnych. Warszawa, Wydawnictwo SGGW.

[27] Komendera, A. (1996). O samorządności wiejskich społeczności w Polsce. In Gorlach, K. \& Seręga, Z., eds., Oblicza społeczeństwa. Kraków: Uniwersytet Jagielloński.

[28] Kotarba, B. (2017). Pozaekonomiczne aspekty likwidacji szkół w gminach wiejskich. Edukacja - Technika - Informatyka 22(4), 50-55. DOI: 10.15584/eti.2017.4.5.

[29] Kovács, K. (2012). Rescuing a small village school in the context of rural change in Hungary. Journal of Rural Studies 28, 108-117. DOI: 10.1016/j.jrurstud.2012.01.020.

[30] Kramer, C. (2019). A multilevel view of small schools: changing systems in BadenWurttemberg and Vorarlberg. In Jahnke, H., Kramer, C. \& Meusburger, P., eds., Geographies of Schooling (pp. 219-249). Cham: Springer. DOI: 10.1007/978-3-030-187996.

[31] Krishna, A. \& Uphoff, N. (2002). Social capital and watershed management. In Grootaert, Ch. \& van Bastelaer, Th., eds, The role of social capital in development. An empirical assessment (pp. 85-124). Cambridge University Press. DOI:10.1017/CBO9780511492600.

[32] Kroismayr, S. (2017). Die Nutzung aufgelassener Schulgebäude und ihre Bedeutung für die Dorfgemeinschaft. Land-Berichte 20(2), 43-58.

[33] Kvalsund, R. (2019). Bigger or better? Research-based reflections on the cultural deconstruction of rural schools in Norway. In Jahnke, H., Kramer, C. \& Meusburger, P., eds., Geographies of Schooling (pp. 189-217). Cham: Springer. DOI: 10.1007/978-3-03018799-6.

[34] Laschewski, L. (2009). The formation and destruction of social capital - lessons from East German rural restructuring. Eastern European Countryside 15, 91-110.

[35] Mikiewicz, P. (2014). Kapitał społeczny i edukacja. Perspektywy teoretyczne i aplikacje empiryczne. Warszawa: PWN.

[36] Perepeczko, B. (2009). Zmiany ilościowe i jakościowe w rolnictwie a lokalny kapitał społeczny. In Psyk-Piotrowska, E., ed., Kapitał społeczny. Partycypacja obywatelska. Rozwój lokalny. UŁ, Łódź, pp. 80-89.

[37] Preston, J. P. \& Barnes, K. E. R. (2017). Successful Leadership in Rural Schools: Cultivating Collaboration. Rural Educator 38(1), 6-15.

[38] Putnam, R. (2000). Bowling alone: the collapse and revival of American community. New York: Simon \& Schuster. 
[39] Raggl, A. (2015). Teaching and learning in small rural primary schools in Austria and Switzerland - opportunities and challenges from teachers' and students' perspectives. International Journal of Educational Research 74, 127-135. DOI: 10.1016/j.jijer.2015.09.007.

[40] Raggl, A. (2019). Small rural schools in Austria: potentials and challenges. In Jahnke, H., Kramer, C. \& Meusburger, P., eds., Geographies of Schooling (pp. 251-263). Cham: Springer. DOI: 10.1007/978-3-030-18799-6.

[41] Siellawa-Kolbowska, E. (2011). Społeczni partnerzy w edukacji. Wzory i praktyki in statu nascendi z perspektywy socjologa. In Domalewski, J. \& Wasielewski, K., eds., Zmiany w edukacji: szkoła i jej społeczne otoczenie. Z prac Sekcji Socjologii Edukacji i Młodzieży PTS, tom 1. Toruń: Wyd. Adam Marszałek (pp. 146-173).

[42] Svendsen, G. L. H \& Sørensen, J. F. L. (2016). Skolelukninger på landet. En undersøgelse af skolelukningsforløb i Tønder Kommune 2010-11, samt lukningernes konsekvenser for de berørte lokalsamfund [CLF REPORT 56/2016]. Odense: Syddansk Universitet.

[43] Svendsen, G. L. H. \& Svendsen, G. T. (2004). The creation and destruction of social capital: entrepreneurship, co-operative movements and institutions. Cheltenham: Elgar.

[44] Uphoff, N. (2000). Understanding social capital: learning from the analysis and experience of participation. In Dasgupta, P. \& Serageldin, I., eds., Social capital: a multifaceted perspective (pp. 215-250). Washington D.C.: The World Bank.

[45] Viñas, C. D. (2019). Depopulation processes in European rural areas: a case study of Cantabria (Spain). European Countryside 11(3), 341-369. DOI: 10.2478/euco-2019-0021.

[46] Witten, K., McCreanor, T., Kearns, R. \& Ramasubramanian, L. (2001). The impacts of a school closure on neighbourhood social cohesion: narratives from Invercargill, New Zealand. Health \& Place 7, 307-317. DOI: 10.1016/S1353-8292(01)00023-5.

[47] Woolcock, M. \& Narayan, D. (2000). Social capital: implications for development theory, research, \& policy. The World Bank Research Observer, 15(2), 225-249.

[48] Yin, R. K. (2002). Case Study Research: Design and Methods. Thousand Oaks, CA: Sage Publications.

[49] Young, H. L. (2016). The small rural school and community relations in Scotland, 18722000: an interdisciplinary history [PhD theses]. University of Stirling.

[50] Zhumashov, Y. \& Tomanova, M. (2014). Demographic impact of Kazakhstan's countryside education. Procedia - Social and Behavioral Sciences 143, 279-281. DOI: 10.1016/j.sbspro.2014.07.404.

[51] Zuckerman, S. J. (2019). Making Sense of Place: A Case Study of a Sensemaking in a Rural School-Community Partnership, Journal of Research in Rural Education 35(6), pp. 1-18. DOI: 10.26209/jrre3506.

\section{Other sources}

[52] [dataset] Central Statistical Office, 1995 to 2012. Education in the school year ... issues from 1994/1995 to 2011/2012. Warsaw.

[53] Data sent by e-mail by local authorities.

[54] Interviews (described in the methods section).

[55] Które szkoły do kasacji? Gazeta Współczesna 1.03.2000 No.43(14454).

[56] Productivity Commission Research Paper, 2003. Social capital: reviewing the concept and its policy implications. AusInfo, Canberra. 